\title{
The effect of intellectual capital disclosure on the value creation: An empirical study using Tunisian annual reports
}

\author{
FERCHICHI Jihene \\ Dept. of Accounting and Finance-FSEGT - Tunis El Manar - TUNISIE
}

Tel : (+216) 20297 277. E-mail : cheninijihene@yahoo.fr

PATUREL Robert

Professor - IAE - UBO - FRANCE

Received: February 02, 2013 Accepted: March 05, 2013 DOI: 10.5296/ijafr.v3i1.3238

\begin{abstract}
This study examines the informational value of intellectual capital on Tunisian financial markets, which appears as a highly topical issue, especially with the broadening notion of the intellectual capital and its increasing role in investment decisions. Using content analysis of annual reports of 50 companies listed on the Tunisian Stock Exchange selected for the period 2006-2009, we developed a weighted disclosure index based on the users' needs and expectations in order to estimate the relationship between intellectual capital disclosures and value creation.

The results show that the intellectual capital information is positively and significantly correlated with the firm creation value. Reporting on intellectual capital allows resolving uncertainty about the firm, thereby improving an increase in value. This finding confirms the pivotal role of intellectual capital in the valuation of firms listed on the Tunisian Stock Exchange.
\end{abstract}

Keywords: Intellectual capital, value creation, financial market, voluntary disclosure, annual reports. 


\section{Introduction}

The disintermediation of the economy and the development of financial markets in recent years have significantly altered the financial reporting policy of listed companies (Léger, 2003). Previously designed to meet the legal requirements, the financial reporting have become an important tool used voluntarily by companies to disseminate their own image. The voluntary information occupies an important area in the literature (Lev, 1992). This voluntary information was mainly focused on the release of earnings forecasts (Clarkson and al. 1992 Jog and McConomy, 2003; Labegorre and Boubaker, 2005). Therefore, financial statements suffer from a lack of timeliness, and a limited ability to convey prospective data and risks facing the firm. In this context, investors, as users of financial information, are increasingly aware of the importance of company information that is not directly reflected in financial statements. Intellectual capital has become an important source of corporate value and firm wealth in our era of globalization (Garcia-Meca and Martinez, 2005). More recent works explore this new facet of voluntary information and noted that information including intellectual capital is considered as quality signals from investors.

Prior research (Chauvin and Hirschey, 1994; Eccles and Mavrinac, 1995; Barth and Clinch, 1998; Fernandez, and Vazquez Montes, 2000; Barth and al., 2000; Eccles and al. 2001 , Lev, 2001; Beattie and Pratt, 2002a, 2002b; Chahine and Mathieu 2003; Lev and al., 2003; Cazavan-jeny, 2004; Garcia-Meca and Martínez, 2007) has shown that the intellectual capital information have $\mathrm{n}$ important role in signaling the situation of the company by highlighting a significant relationship between firm value and the level of its intellectual capital disclosure. This position supported by signal theory and agency theory, states that managers can benefit from the disclosure of intellectual capital information, especially in its optional, to signal to the market their future performance and reduces agency costs. These researches are promising and open the debate on how investors perceive and value the intangibles information communicated to them by companies.

In this study, we are going to evaluate the informational value of intellectual capital in the financial market. We ask, in particular, if firms can signal their quality to the financial market through a voluntary effort on their publication of intellectual capital information.

The underlying methodology is a comprehensive analysis of the intellectual capital disclosure in 50 annual reports for Tunisian listed firms from 2006 to 2009. To carry out this approach, we have developed a weighted disclosure index to quantify the effort of publishing companies on their intellectual capital, based on users' needs and expectations (portfolio managers and financial analysts). This disclosure index will be operated in our empirical model that focuses on the assessment of the informational value of data on intellectual capital and its ability to create value in the financial market. As predicted, our results show that reporting on intellectual capital is positively and significantly correlated with the firm creation value

These findings may help to improve methodologies to assist investment decision makers. The results also have implications for financial reporting policy. The influence of intellectual capital in financial market has led policy makers and accounting standard-setting boards to 


\section{MInstitute Macrothink $_{\text {Int }}$}

International Journal of Accounting and Financial Reporting ISSN 2162-3082 2013, Vol. 3, No. 1

consider proposals to enhance information on intellectual capital in corporate financial statements. In order to establish a policy, one needs to know how investors actually use both financial and non-financial information (Schipper, 1991).

The remainder of this paper is organized as follows. Section 2 reviews the previous theoretical and empirical research; the methodology and study design are discussed in the third section; the fourth section presents the test results; and the final section of the paper summarizes the conclusions, describes limitations, and discusses implications for future research.

\section{Literature review and hypothesis}

The broadening notion of the intellectual capital and its increasing role in investment decisions have provided evidence on the financial markets that the value of a company comes from its intellectual capital. Meanwhile, financial reporting is strongly influenced by the tools of the industrial era and the traditional accounting. This last find difficulties to measure intellectual capital and, by necessity, privileged tangible assets while ignoring the immaterial elements of a company value. (Kaplan and Norton, 2001; Ittner and al, 2003; Kennerley and Neely, 2003). Therefore, the problem with the traditional financial accounting framework is the failure to publicise the most important assets and resources of today's business that creates an information gap between insiders and outsiders. The only intellectual capital recognized in the financial statements was intellectual property such as patents, trademarks. A substantial part of firm's assets is reported only partially in the financial statements. Because of the relative lack of accounting recognition of intellectual capital and their growing importance in the value creation, the financial statements lost a part of their value in the eyes of shareholders who cannot recover from it any more to have a complete image of a company, which affects how they make their investment decisions. If the other information does not come to fill this void, there could be a misallocation of resources in the financial markets. Thus, several efforts have been implemented by accounting standard-setting boards. In Tunisia, for example, the representation tools in accounting intangible investment have evolved considerably during these last years with the adoption of the Accounting Standard relative to intangible assets (NCT 06), and by that relative to the Research and Development expenses (NCT 20). The development of these accounting rules has offered companies new opportunities for recognition of intangible investment in their assets. However, despite these developments, the accounting information about intangible elements suffers from several critics because of its inability to identify certain intangible assets and to recognize them as separate capital. In front of the multitude of constraints between the considerations of certain intangibles in conventional financial statements, several companies are voluntarily opting to include information on their intangibles in the notes to their annual reports. In this new mode of "reporting", the publications of intellectual capital are an increasingly growing. Many few studies exploring this new facet of the voluntary information covering intellectual capital and its role in reducing information asymmetries in the financial market.

In this context, Mavrinac and Siesfield (1997), Miller (1999) and Bournemann and al. (1999) appreciated the usefulness of intellectual capital information. A comparison of the three 


\section{Ml Macrothink}

International Journal of Accounting and Financial Reporting ISSN 2162-3082 2013, Vol. 3, No. 1

studies is shown in Table 1. The findings showed that managers perceived intellectual capital information as being the most useful. Miller (1999) determined the top four information to be leadership skills, employee satisfaction, and employee motivation and there experience. The results of Bournemann et al.'s research support the findings of Mavrinac and Siesfield (1997) that information for strategy implementation, market share, innovativeness and the company's ability to attract and retain talented employees are crucial. The results point towards a need for companies to adopt a more comprehensive approach to managing intellectual capital. Successful companies were also found to manage intellectual capital better than less successful firms.

Table 1. Comparison of the usefulness of intellectual capital information

\begin{tabular}{|l|l|l|l|}
\hline Intellectual capital Information & $\begin{array}{c}\text { Mavrinac and } \\
\text { Siesfield (1997) }\end{array}$ & Miller (1999) & $\begin{array}{c}\text { Bournemannet } \\
\text { al. (1999) }\end{array}$ \\
\hline Leadership skills & & 1 & \\
\hline Execution of corporate strategy & 1 & & 3 \\
\hline Management credibility & 2 & 3 & \\
\hline Employee motivation & & 4 & \\
\hline Employee satisfaction & & 6 & 6 \\
\hline Employee experience & 5 & & \\
\hline Ability to attract employees & 7 & & 5 \\
\hline Management experience & 8 & & 1 \\
\hline $\begin{array}{l}\text { Quality of compensation } \\
\text { policies }\end{array}$ & 5 & 2 & 8 \\
\hline Customer satisfaction & 6 & 7 & \\
\hline Market share & 3 & & 4 \\
\hline $\begin{array}{l}\text { Number of } \\
\text { complaints }\end{array}$ & 5 & & 7 \\
\hline Quality of corporate strategy & 3 & & \\
\hline Innovativeness & 4 & & \\
\hline Quality processes & 5 & & \\
\hline
\end{tabular}

Derived from Brennan and Connell (2000)

These studies were largely confirmed by the Frotiee and Andrieu (1998) research in which it appears that a number of non-financial information is particularly important for users. Indeed, this researcher has shown that users have a strong interest in information measuring the quality of production processes, its ability to innovate and customer satisfaction. The authors have found that the forecast errors decrease proportionally with the increase of analyzes based on intellectual capital information. The latter can exceed a superficial analysis of the company incorporating elements related to its strategy, organization, management and its customers. However, the authors believe that disclosure in this area does not meet the user expectations. The result of this study is shown in Table 2 . 
Table 2. The usefulness of non-financial indicators by investors

\begin{tabular}{|c|c|c|c|}
\hline Indicators & $\begin{array}{c}\text { Financial indicators } \\
\qquad(\mathrm{F}) \\
\text { Non-financial } \\
\text { indicators (NF) }\end{array}$ & $\begin{array}{l}\text { Importance } \\
\text { of } \\
\text { indicators }\end{array}$ & $\begin{array}{c}\text { Adequacy needs } \\
\text { versus the } \\
\text { current } \\
\text { publication }\end{array}$ \\
\hline Market Growth & NF & $92 \%$ & $84 \%$ \\
\hline Earnings & $\mathrm{F}$ & $92 \%$ & $92 \%$ \\
\hline Investments & $\mathrm{F}$ & $90 \%$ & $92 \%$ \\
\hline Innovativeness & NF & $90 \%$ & $77 \%$ \\
\hline Cash Flows & $\mathrm{F}$ & $90 \%$ & $90 \%$ \\
\hline Quality of corporate strategy & NF & $86 \%$ & $84 \%$ \\
\hline quality products & NF & $84 \%$ & $31 \%$ \\
\hline Investment in R \& D & $\mathrm{F}$ & $84 \%$ & $90 \%$ \\
\hline Production cost & $\mathrm{F}$ & $84 \%$ & $84 \%$ \\
\hline Market share & NF & $82 \%$ & $63 \%$ \\
\hline Employee experience & $\mathrm{NF}$ & $73 \%$ & $43 \%$ \\
\hline Customer loyalty & $\mathrm{NF}$ & $64 \%$ & $18 \%$ \\
\hline $\mathrm{R} \& \mathrm{D}$ productivity & NF & $61 \%$ & $12 \%$ \\
\hline Intellectual Property & NF & $59 \%$ & $39 \%$ \\
\hline customer satisfaction & NF & $57 \%$ & $8 \%$ \\
\hline Quality processes & NF & $55 \%$ & $29 \%$ \\
\hline
\end{tabular}

Derived from Andrieu and Frotiée (1998)

Amir and Lev (1996) research of 14 cellular telephony providers in the U.S.A for the period from 1984 to 1993 showed that while intangible assets contribute to the market value of these firms, current accounting rules do not allow recording these assets. Consequently information provided in financial statements is useless to investor when valuing the firms with large amounts of intangible assets. Amir and Lev (1996) found that earnings, book values and cash flows are largely irrelevant on a stand-alone basis when valuing companies in the cellular telephone industry. They concluded that the information on the intellectual capital significantly influence the value of the high-technology companies and even sectors of growth more generally. Shevlin (1996) confirms theses results and calls to generalize them to other activity sectors of the economy.

Lev (2001) suggests that there is a positive correlation between intellectual capital disclosure and market capitalisation which is also likely to be a key motivator for listed firms to voluntarily adopt disclosure of intellectual capital.

Dempsey, Gatti, Grinell, and Cats-Baril (1997) survey of 420 financial analysts determined the top four relevant information for users that is management experience, potential competition, market share, and brand awareness. While surveys may give us some useful descriptions of the perceived requirements of financial analysts. Similarly, Beattie (1999) 
survey of 154 users of accounting information determined the quality of management as the key factor determining success of a company.

Using an alternative approach, Previs et al. (1994) research of 479 sell-sides analyst company reports find that financial analysts make extensive use of intellectual capital information related to competitive position, quality of management, and corporate strategy. Rogers and Grant (1997) analyze 187 analyst reports, and note that the narrative sections of annual reports are cited almost twice as often as the financial statements which demonstrated its importance. Deeds et al (1997) found that the publication record of technological development was positively correlated with the amount of capital the company could raise in its initial public offering-IPO. This has led managers to use this information to signal their quality to financial market. Decarolis and Deeds (1999) research of corporate biotechnology show that managers report the quality of their business through technology variables (R\&D, intellectual property ...) and human variables (management skills). Their signal reveals the company's ability to manage its resources optimally.

In london, Breton and Taffler (2001) explore 105 sell-side analyst reports. They conclude that financial analysts give particular interest to firm management, strategy, and trading environment when making an investment recommendation. Management issues appear to dominate analysts' rationales for recommendations.

Cazavan-Jeny (2004), using panel data of 63 listed French firms for the period 1994-1999, explained differences between the market value and book value of a company. She proposed the hypothesis that this difference can be attributed to the fact that intangible assets are not reflected in financial statements. Her results indicate a statistical link between the capitalised goodwill and the market-to-book ratio.

Garcia-Meca and Martinez (2005) survey of 260 full-text sell-side analyst reports on Spanish listed companies examines how much financial analysts use intellectual capital information in their reports. The result of this study is shown in Table 3. The findings showed that the existence of intellectual capital information is considered useful by stakeholders. It determined the most useful one which are Corporate Strategy, organization customers, human capital, innovation, research and development. Therefore, the authors suggested that reporting company should be more willing to disclose such information.

Table 3. The usefulness of intellectual capital information

\begin{tabular}{|c|l|l|l|l|l|}
\hline $\begin{array}{c}\text { Intellectual } \\
\text { capital } \\
\text { information }\end{array}$ & $\begin{array}{c}\text { Corporate } \\
\text { Strategy }\end{array}$ & Organization & Customer & $\begin{array}{c}\text { Human } \\
\text { Capital }\end{array}$ & $\begin{array}{c}\text { Innovation, } \\
\text { research and } \\
\text { development }\end{array}$ \\
\hline $\begin{array}{c}\text { Importance } \\
\text { in investment } \\
\text { decisions }\end{array}$ & $100 \%$ & $60 \%$ & $66 \%$ & $44.24 \%$ & $41.47 \%$ \\
\hline
\end{tabular}

Liang and Yao (2005) research of listed Taiwanese electronic firms found that intellectual capital information is the most significantly explanatory capability in market value financial. Therefore, they added that analysts should given a great interest to this information prior to 
judge the value of firms. Lev (2002), using 844 observations of listed American pharmaceutical industry firms, reported that intellectual capital has been identified as a set of intangibles that drives the financial performance and value creation. Chen, Cheng, and Hwang, (2005) investigated empirically the relation between the value creation efficiency and firms' market valuation and financial performance. Using data drawn from Taiwanese listed companies and Pulic's Value Added Intellectual Coefficient (VAIC ${ }^{\text {TM}) ~ a s ~ t h e ~ e f f i c i e n c y ~}$ measure of capital employed and intellectual capital, the authors construct regression models and reported that firms' intellectual capital has a positive impact on market value and financial performance, and may be an indicator for future financial performance. They added that R\&D expenditure may capture additional information on structural capital and has a positive effect on firm value and profitability. Firer and Williams (2003), using the same approach to value intellectual capital, found similar results.

Another study in value-relevance on accounting information for intangible intensive firms is Abdolmohmmadi (2005). Using content analysis of 284 randomly selected annual reports over a five-year period (1993-1997) in the US, he found a strong positive association between intellectual capital disclosure and market value of firms.

Dammak and al (2009) developed a Structural equation modelling to study the effect of intellectual capital information (human and structural capital) on the financial market. Results based on annual reports of 71 multinational observed in 2005, determined statistical link between voluntary intellectual capital disclosure and stock market value.

Bellalah and Bouri (2010) studied the value relevance of the financial information on the intangible investments for the investors on the Tunisian stock market. Their results showed that the activation of the investments immaterial influence positively their assessment on the market, and that the depreciation of intangible assets is valorised positively by the investors on the stock market. These finding showed that the financial information on the intellectual capital have an informative value for the investors on the stock market.

Another recent study in value-relevance on accounting information for intangible intensive firms is Hsiung and Wang (2012). This work calculated the value of intangible assets in Taiwan's digital content industry based on five valuation models for intangible assets (the market capitalization methods of MV/BV and Tobin's q, and the return on assets methods of CIV, EVA, and VAICTM), and also conducted comparative analysis of the various valuation methods. The authors concluded that there is a high correlation between market capitalization type valuation methods, but low correlation between the return on asset type methods. Therefore, when valuating intangible assets, the objectives must be very clear and the valuation method must be chosen carefully. An appropriate method must be chosen from the perspective of suitability to prevent false estimation of the company's real value. The study also proved that the four dimensions of financial assets and intellectual capitals (structural, human, and relationship capitals) are not individually related to the company's value creation, and they have mutual contribution, advancement, and growth. The greater the synergy produced by their interaction, the greater the contribution they make to the value of the company. 


\section{Mll Macrothink}

International Journal of Accounting and Financial Reporting ISSN 2162-3082 2013, Vol. 3, No. 1

There was created a plenty of theories and concepts to measure intangible assets or intellectual capital and its components. Some of them tend to measure value created by intellectual capital or its quantity, while others are dedicated to determine the level of its influence on company performance. But until now there have been no generally accepted methods that allow achieving those goals. Some of them are based on interviews and questionnaires, others use available financial information. Really, there are very few studies which have examined the intellectual capital in a comprehensive. Arvidsson (2003) and Béjar (2006) are ones. Arvidsson (2003) analyzed 105 analyst reports on knowledge-intensive companies in Nordic countries, using a disclosure index of 81 items classified into five categories: human, relational, organizational, $\mathrm{R} \& \mathrm{D}$, and environmental/social. Her disclosure scores showed that financial analysts focus primarily on information regarding R\&D and customers, and include little information on organizational or human capital. Analyst reports on internationally listed companies are more likely to include more information on intellectual capital.

Béjar (2006) examined the informational value of intellectual capital in the European initial public offering (IPO) prospectus using multiple regression analysis. The sample consists of 107companies in the technology sectors of Euronext Paris that went through an IPO between 1996 and 2004. Using a disclosure index of 19 items classified into six categories: corporate management, human resources, relational, organizational, innovation, and environment, she tested the existence of any association between the quality of intellectual capital disclosure and underpricing. Results showed that the quality of informational effort done by high technology firms on its intellectual capital is perceived as a positive signal by capital markets.

Previous studies tended to focus on the effect of intellectual capital disclosure on corporate value creation in financial market. Accordingly, the following hypothesis is advanced:

\section{Hypothesis:}

\section{Intellectual capital information disclosed voluntarily is positively related to a corporate value creation in financial market.}

\section{Methodology and design}

The review of the empirical literature examines how much investors use intellectual capital information in their financial decision and whether there is a relationship between this information and value creation in financial market. It is therefore useful to spread knowledge on this topic and to see if the intellectual capital's role keeps in a different environment such the one of Tunisia.

\subsection{Sample Selection}

Our study sample consists of 50 firms listed on the Tunisian stock exchange. Selected firms belong to various sectors: financial services, energy, communication, etc.. Select multiple industries allowed to have different categories of intangible (E. García-Meca, I. Martínez, 2007; Wlliams S. M., 2001) and to avoid specific correlation effects to a particular sector. 


\section{Mll Macrothink}

International Journal of Accounting and Financial Reporting ISSN 2162-3082 2013, Vol. 3, No. 1

Data used is provided by the Tunisian Stock Exchange and the Council of Capital Market through respectively their official bulletins and their annuals reports covering the period from 2006 to 2010. The analysis is about the period from 2006 to 2009. The year 2010 serves to calculate some parameters of Tobin's q reflect the reactions of stock market investors that need a period of time to occur. The total number of observations is 200 observations. However, some of the observations need to be dropped due to unavailability of data and some companies were not listed on the Tunisian stock exchange in all the four years' period. This reduced the final observations to 191 observations. Table 4 shows the sample distribution by industry.

Table 4.Sample distribution by industry

\begin{tabular}{|l|c|c|}
\hline \multicolumn{1}{|c|}{ Industry } & Number of firms & \% of firms \\
\hline Financial services & $\mathbf{1 6}$ & $\mathbf{3 2 \%}$ \\
\hline Communications & $\mathbf{4}$ & $\mathbf{8 \%}$ \\
\hline Consumer Services & $\mathbf{5}$ & $\mathbf{1 0 \%}$ \\
\hline Health & $\mathbf{3}$ & $\mathbf{6 \%}$ \\
\hline Consumer Goods & $\mathbf{8}$ & $\mathbf{1 6 \%}$ \\
\hline Industry & $\mathbf{7}$ & $\mathbf{1 4 \%}$ \\
\hline Basic materials & $\mathbf{4}$ & $\mathbf{8 \%}$ \\
\hline Energy & $\mathbf{3}$ & $\mathbf{6 \%}$ \\
\hline Total & $\mathbf{5 0}$ & $\mathbf{1 0 0 \%}$ \\
\hline
\end{tabular}

\subsection{Variables and measures}

\subsubsection{Dependent variable : firm value}

A wide-ranging literature review reveals many perspectives on value creation, accordance with the topic of this study, which examines the value creation in the financial markets; it is required to adopt the financial perspective one. This last has focused on the question of company value (Stewart, 1991). A number of investigations utilize a variety of approach in valuing a company as Return on Assets (ROA), Tobin's Q etc.

We adopt Tobin's q as our measure of firm value, rather than Return on Assets, because Tobin's q reflects expected future earnings and captures the lag between intellectual capital investment and realized benefits.

Tobin's q is the market valuation of a firm over the value of its tangible assets and is a good proxy for a firm's competitive advantage (Montgomery and Wernerfelt, 1988). The theory is that if $\mathrm{q}$ is greater than 1 and greater than competitors' $\mathrm{q}$ then the company has the ability to produce higher profits than other similar companies. The company has something intangible (intellectual capital) that gives it an advantage. Therefore, Tobin's Q is appropriate for evaluating the results of intellectual capital since it is a forward-looking measure featuring a 
firm's future performance potential.

Following the difficulties in estimating the parameters of Tobin's q (market value, replacement costs), we use a simple approximation to the theoretical Tobin's q measure. This approximation requires only publicly available financial and accounting information. In this approach, $\mathrm{q}$ is measured by dividing the sum of firm equity value, book value of long term debt, and net current liabilities by total assets. We do not calculate replacement values using the method proposed by Lindenberg and Ross (1981) because past research has found little qualitative difference between this measure and the approximation measure used in this study (Chung and Pruitt, 1995), so approximate Q can explain at least $96.6 \%$ of the theoretical Tobin's q.

Finally, it is necessary to determine the period in which the parameters of Tobin's Q.

To measure Tobin's $\mathrm{Q}$ of the firm for the year N, the book value of long term debt, net current liabilities and total assets are extracted from the financial statements of this year, nevertheless, we should using firm equity value for the year $\mathrm{N}+1$, because this last parameter reflect the reactions of stock market investors which need a period of time to occur especially as the financial statements for the year $\mathrm{n}$ are published in the following year.

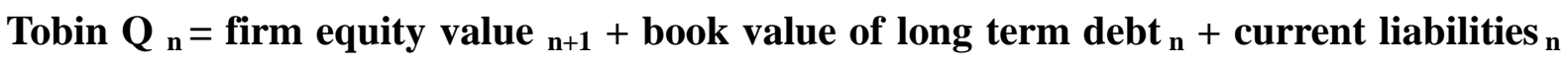
/total assets $n$

\subsubsection{Independent variable: Intellectual Capital Disclosure Index}

The focus of this study is on the role played by intellectual capital information as a significant determinant of the market value of the firm as measured by Tobin's. Therefore, our independent variable is the level of Intellectual Capital Disclosure and it was measured using a disclosure index, a technique used by a variety of prior accounting disclosure studies (Cooke, 1989).

For the purpose of this study, the analysis is based on weighted disclosure index. This approach consists in assigning to each item a weighting that translates the relative importance of this item depending on the group of users (Michailesco, 1999). It reflects both the extent and importance of each disclosure item that forms the index (Robbins \& Austin, 1986). Indeed, intellectual capital information can not be perceived by the market as a signal to create value only if it is conform to users' needs and expectations (Béjar, 2006).

We develop a self-constructed index that we call the Intellectual Capital Disclosure Index (ICDI), which reports the percentage of intellectual capital information disclosed over a predefined list of items. However, there are no theoretical guidelines for selecting items, and successful application of the disclosure indexes depends on critical and careful selection. From an extensive review of the intellectual capital literature preliminary disclosure index comprising 59 items was formed. Following exploratory survey with 22 financial analysts and portfolio managers to eliminate irrelevant items, a total of 18 items were eliminated from 


\section{Macrothink}

International Journal of Accounting and Financial Reporting

ISSN 2162-3082 2013, Vol. 3, No. 1

the preliminary list. Therefore, the index consists of 41 different items. The literature concerning intellectual capital proposes different ways to classify intangibles. There is no general agreement on boundaries between categories or into which category a certain type of intangible falls. We classify the items into nine different categories: corporate management; corporate governance; human resources; organization; innovation; customers; environment; ethics; and corporate reputation. These categories serve to provide a structured vision of the resources available to a company.

Using the Delphi method (3iterations), the Intellectual Capital Disclosure Index is weighted by the importance given to each item of disclosure by previous respondents (22 financial analysts and portfolio managers). Respondents have been called to express the degree of importance they give to the items by giving a note in the Likhert 5 points scale (with $1=$ not important to $5=$ very important). Every diffused item is weighted by the mean of the points that are attributed to him (Buzby, 1975). The second used procedure is the following: an item takes the "weight" that has been attributed to him by the financial analysts and portfolio managers if it is disclosed and " 0 " otherwise.

To calculate this disclosure index, we used content analysis of annual reports as source documents as they are most widely distributed and regularly produced documents. Annual reports are a channel that a firm seeks to establish an image in the public domain, and communicates with investors (Lang \& Lundholm 1993).

The Intellectual Capital Disclosure Index scored by each company and weighted by respondents was then divided on the total value of the index by the maximum number of items for each firm. The index denominator is considered as the optimum of intellectual capital disclosure expected by financial market to be published by firms.

The index can be presented as follows:

$$
\begin{gathered}
\mathbf{I C D I}_{\mathbf{i}}=\sum_{j=1}^{9} \mathbf{P}_{\mathbf{j}} \quad \mathbf{x} \mathbf{P}_{\mathbf{k j}} \quad \mathbf{x} \mathbf{X k j} \\
\sum_{k=1}^{n 2 .} \mathbf{P}_{\mathbf{k j}} \quad \mathbf{x} \mathbf{X k j}
\end{gathered}
$$

Where,

- ICDIi = Intellectual Capital Disclosure Index for $i$ th firm;

- $\mathrm{P}_{\mathrm{i}}=$ weight for $j$ th category;

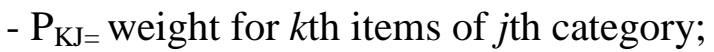

- $X_{\mathrm{kj}}=1$, if $k$ th items of $j$ th category are disclosed for firm $\mathrm{i}$, otherwise 0 ; 


\section{Macrothink}

International Journal of Accounting and Financial Reporting

- $\mathrm{N}_{1}=$ number of item of $j$ th category disclosed by the firm $\mathrm{i}$;

- $\mathrm{N}_{2}=$ Maximum number of Item expected by financial market, which may not exceed 41 , with $\mathrm{n}_{1} \leq \mathrm{n}_{2}$.

We assess the validity of the disclosure index using Cronbach's alpha. It evaluates how well a set of items - namely, the nine categories of intellectual capital - measures a common entity, in this case intellectual capital information. If the intercorrelation among items is high, the items measure the same construct. Our Cronbach's alpha is 0.7138, indicating internal consistency in the disclosure index.

\subsubsection{Control variables}

To isolate the effects of other factors with predictable influences on the market value of the firm, we include corporate size, leverage, profitability, firm age and as control variables.

\section{- Corporate size}

Corporate size, as measured by assets, turnover, or capitalization, has been positively associated with firm value in numerous studies, suggesting that larger companies follow better performance than smaller companies because it receives a high level of attention from the general public, which may, in turn, encourage the firms to create more value in the financial market (2001, Henning et al, 2000 Cazavan-jeny, 2004; Delgado-Gomez et al, 2004; Louzzani, 2004; Arcelus et al, 2005; Bouden, 2006; Casta et al, 2007).

In this study, we use a proxy measure of firm size which is a natural logarithm of total assets excluding intangible ones. The use of the logarithm is justified by the objective of mitigating heteroscedasticity problems.

\section{LNTA = Log (total assets).}

We expect a positive relation between the firm size of the firm and its ability to create value in financial market.

\section{- Profitability}

Profitability is another factor that should affect Tobin's q. In their studies, Cazavan-Jeny (2004), Bouden (2006) and Casta et al. (2007) argued that profitability has a positive effect on market values. It is reasonable to expect a positive valuation effects of profitability because it is considered by users as the best available indicator of a firm's ability to generate superior rates of return during future periods.

This variable is measured as the ratio of Earnings before interest and taxes to total assets.

\section{PROF = Earnings before interest and taxes/ total assets.}

We wait for a positive relation between the profitability of the firm and value creation.

\section{- Leverage}

Debts represent the firm's financial policy; therefore, it is determinant to firm value creation in financial market. But, no consensus exists on the effects of financial leverage on value 
creation. Empirical studies that analysis this effect have produced mixed results. On the one hand, some authors find an inverse relationship between leverage and value creation, for example Rajan and Zingales (1995). Other studies suggest a positive relationship. This variable is measured as the ratio of the sum of all debts to total assets.

\section{END = total debts / total assets.}

\section{- Firm age}

Empirical studies outlined that the experience of the company influences its performance and its ability to create value in financial market. Haniffa and Cooke (2002) have used the variable listing duration among the variables that characterize the firm. Gantenbein and Volonté (2012) have used this variable among the factors that can affect firm performance because mature firms have the possibility to improve their value creation across the time. The age of the company is measured by the logarithm of the duration of the firm listing in the stock exchange in years. The use of the logarithm is justified by the objective of mitigating heteroscedasticity problems.

\section{LNCOT $=$ Log (duration of the listing of the firm in the stock exchange in years).}

We expect a positive relation between the period of listing and the firm value creation.

\section{- Business classification}

The value creating ability differs depending on the kind of industry a firm belongs to. Eberhart, Maxwell and Siddique (2004) showed that high-tech firms have better performance than low-tech firms. To isolate the business classification effect on value creation firm, we use this factor as control variable, and we classify our sample into high/low tech industry affiliation. However, there are no theoretical guidelines for firm technologic classification. Following to the purpose of this study, we select firm R\&D intensity as a criterion for the classification issue. $R \& D$ intensity is considered as an indicator of the technological opportunity in an environment, which means the degree to which a firm's market demands or accepts product innovation. We measured firm $R \& D$ intensity as the ratio of the firm $R \& D$ expenditures to firm sales.

Precisely, we establish two firm groups from the comparison of firm intensity R\&D to the average of $R \& D$ intensity of all sample's firm: firms whose R\&D intensity is higher than the average will be considered as high tech firms, while other firms will be called low-tech. This approch has been adopted by Lev and Zarowin (1999).

This control variable CLA is a dummy variable that equals one for high-tech industry, and zero otherwise.

\subsection{Empirical design and statistical method}

Our basic purpose in this paper is to present evidence on the valuation consequences of intellectual capital disclosure, controlling for a variety of other factors than can affect company value. 


\section{Macrothink}

International Journal of Accounting and Financial Reporting ISSN 2162-3082 2013, Vol. 3, No. 1

We regress the Tobin's Q against Intellectual Capital Disclosure Index to gauge her impact on value creation. We estimate a linear regression by generalized least squares. The analysis is based on the multiple-regression model (based on F-test at 0.95 level of confidence (sig. = $0.05))$ :

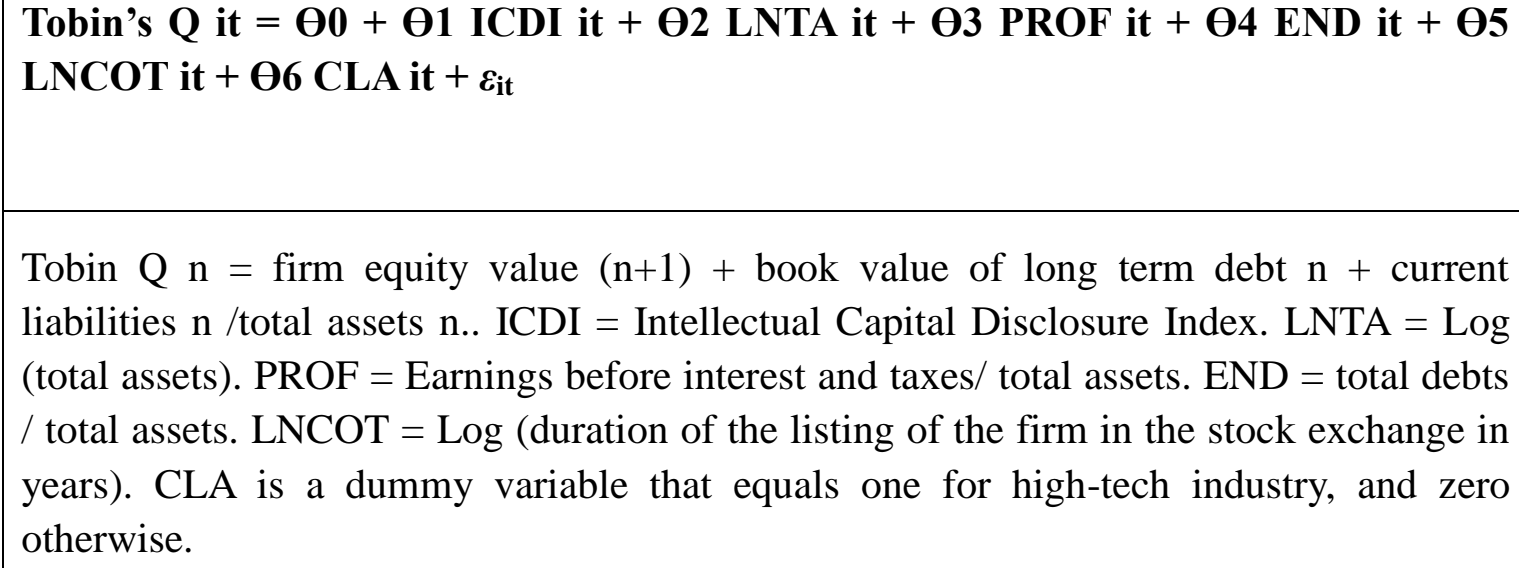
liabilities $\mathrm{n}$ /total assets $\mathrm{n}$. . ICDI $=$ Intellectual Capital Disclosure Index. LNTA $=$ Log (total assets). PROF = Earnings before interest and taxes/ total assets. END = total debts / total assets. $\mathrm{LNCOT}=\log$ (duration of the listing of the firm in the stock exchange in years). CLA is a dummy variable that equals one for high-tech industry, and zero otherwise.

Our study is based on the panel data, that's why it is convenient to verify the homogenous specification of the generator process of the data. We should then distinguish between the specific effect and the common effect through Fisher statistic (test of Chow).

\section{Empirical results}

In the following section, we will analyze and comment our different empirical results.

\subsection{Descriptive statistics}

We are interested in examining the characteristics of study's variables.

Table 5. Descriptive statistics on sample firms

\begin{tabular}{|c|l|l|l|}
\hline Variables & \multicolumn{1}{|c|}{$\mathrm{N}$} & \multicolumn{1}{|c|}{ Mean } & \multicolumn{1}{|c|}{ Standard Deviation } \\
\hline Tobin's Q & 191 & 1.5034 & 0.8210 \\
\hline ICDI & 191 & 0.3646 & 0.2175 \\
\hline LNTA & 191 & 12.032 & 1.7587 \\
\hline PROF & 191 & 0.0529 & 0.0781 \\
\hline END & 191 & 0.6275 & 0.2983 \\
\hline LNCOT & 191 & 11.141 & 5.5947 \\
\hline CLA & 191 & 0.26 & 0.0084 \\
\hline
\end{tabular}

Tobin $\mathrm{Q} n=$ firm equity value $(\mathrm{n}+1)+$ book value of long term debt $\mathrm{n}+$ current liabilities $\mathrm{n}$ /total assets n.. ICDI = Intellectual Capital Disclosure Index. LNTA $=$ Log (total assets). PROF $=$ Earnings before interest and taxes/ total assets. END $=$ total debts $/$ total assets. LNCOT $=$ Log (duration of the listing of the firm in the stock exchange in years). CLA is a dummy variable that equals one for high-tech industry, and zero otherwise. 


\section{Ml Macrothink}

International Journal of Accounting and Financial Reporting

ISSN 2162-3082

2013, Vol. 3, No. 1

This table shows that the firms of our sample are characterizes by a high value of Tobin's Q. We see that the average Tobin's q for the firms in our sample was 1.5. When Tobin's Q is more than one, it indicates that the market value is higher than the total asset value.

The growing difference between the market value and book value of a company is said to represent its intellectual capital. Traditional accounting measures (balance sheet) are inadequate for determining real corporate value especially in the knowledge-based-economy, because they are enabling to convey intangibles. However, investors are increasingly aware of the importance of company information that is not directly reflected in financial statements, that's why, the firm market value which recognizing intellectual capital is higher than her book value. We also notice that the standard deviation is equal to 0.82 , which make us conclude the existence of variability in the behaviour of value creation among the firms of our sample.

The descriptive statistics of the disclosure index (ICDI) shows that disclosures about intellectual capital are generally few (mean is equal to 0.37). This value is close to "1" which is theoretically the highest disclosure index that the company could have if it discloses all the information needs of financial market. The lack of reliable standardized information on intellectual capital is likely to be the reason. Overall, the level of intellectual capital disclosure remains low. The most reported category of intellectual capital was corporate governance and human resources (27\% and $19 \%$ of the items). Information about environment is the second-most cited category, at $15 \%$. Annual reports include, on average, only $12 \%$ of organisation items and $11 \%$ of customers items. However, the least reported was corporate management items at $4 \%$, fear of competitive disadvantage is likely to be the reason. This table shows, also, that the firms of our sample are highly indebted and about $26 \%$ of the sample firms operated in high-tech industry. The standard deviation of the variables LNTA, and LNCOT are very important comparing to the means, which demonstrates the existence of a high disparity between the firms of our sample. This result justifies the use of panel data to control the heterogeneity of the observation in their individual dimensions.

We decompose in table 6 our sample in two groups of firms depending on whether their level of Tobin's Q is lower or higher than 1 in order to determine, particularly, the level of intellectual capital disclosure can characterize every group.

Table 6. Descriptive statistics for lower and higher-Tobin's Q firms

\begin{tabular}{|c|c|c|c|c|c|c|}
\hline & \multicolumn{3}{|c|}{ Panel A } & \multicolumn{3}{|c|}{ Panel B } \\
\hline & Mean & Min & Max & Mean & Min & Max \\
\hline Tobin'sQ & 1.597 & 1 & 5.495 & 0.884 & 0.562 & 0.998 \\
\hline ICDI & 0.488 & 0.037 & 0.872 & 0.195 & 0 & 0.777 \\
\hline LNTA & 12.44 & 9.805 & 15.596 & 11.02 & 9.675 & 15.635 \\
\hline PROF & 0.062 & 0 & 0.678 & 0.050 & -0.200 & 0.205 \\
\hline END & 0.635 & 0.014 & 1.574 & 0.599 & 0.011 & 0.926 \\
\hline LNCOT & 11.76 & 2 & 20 & 10.98 & 1 & 20 \\
\hline CLA & 0.0198 & 0.0021 & 0.0354 & 0.0072 & 0 & 0.0081 \\
\hline
\end{tabular}


Tobin Q $\mathrm{n}=$ firm equity value $(\mathrm{n}+1)+$ book value of long term debt $\mathrm{n}+$ current liabilities $\mathrm{n} /$ total assets $\mathrm{n}$. ICDI $=$ Intellectual Capital Disclosure Index. LNTA $=$ Log (total assets). PROF $=$ Earnings before interest and taxes total assets. END = total debts / total assets. LNCOT $=$ Log (duration of the listing of the firm in the stock exchange in years). CLA is a dummy variable that equals one for high-tech industry, and zero otherwise. Panel A is firms with Tobin's Q is higher than or equal to "1". Panel B is firms with Tobin'Q is lower than less than " 1 ".

Panel A, in which the market value is higher than the book value (mean value is equal to 1.6), have a high level of intellectual capital. This last is unrecognised in balance sheet, but reflected in annual reports with a level of intellectual capital disclosure which equal to 0.49 . Intellectual capital information becomes a new ways of creating business value in financial market. However, panel B that presents a market value lower than its book value, have a law level of intellectual capital disclosure comparing to panel A (this variable is equal, on average, only to 0.19 ).

In the table.7, we are particularly interested in examining the evolution of the intellectual capital disclosure index ICDI between 2006 and 2009.

Table 7. Evolution of intellectual capital disclosure index between 2006 and 2009

\begin{tabular}{|l|l|l|l|l|}
\hline Years & \multicolumn{1}{|c|}{2006} & \multicolumn{1}{|c|}{2007} & \multicolumn{1}{c|}{2008} & \multicolumn{1}{c|}{2009} \\
\hline Mean & 0.239 & 0.3013 & 0.3708 & 0.5512 \\
\hline $\begin{array}{l}\text { Standard } \\
\text { Deviation }\end{array}$ & 0.1385 & 0.1123 & 0.1035 & 0.1018 \\
\hline $\begin{array}{l}\text { Variation } \\
\text { coefficient }\end{array}$ & 0.0325 & 0.0318 & 0.0294 & 0.0281 \\
\hline
\end{tabular}

Through this table, we notice an increase in the extent of voluntary intellectual capital disclosure between 2006 and 2009. This variable has cleary increaed over the period, in the year 2009 we found a value of 0.55 , wheres in the year 2006 it was 0.23 . The study of Naser and Nuseibeh (2003) also demonstrate that the level of voluntary disclosure in annual reports tend to increase across the time. In our case, this increase can be attributed to the following reasons: first, there is increasing evidence that the drivers of value creation in era of globalisation is intellectual capital rather than its physical and financial ones, and then managers report such information to stakeholders to enhance the perceived value of the firm.

Second, the government of Tunisia recently has taken several steps to drive its economy towards a knowledge-based economy. These steps include the recent efforts that have been implemented by Financial Market Council to enhance market transparency and good corporate governance.

We also have done an additional analysis like Singleton and Globerman (2002) to verify if the voluntary disclosure practices tend to diverge or converge among the firms of our sample. The comparison of the coefficient of variation of the disclosure indexes over the period from 2006 to 2009 allow us to detect a decrease of this coefficient which means that intellectual capital disclosure behavior in our firm sample tend to converge across the time. 


\subsection{Bivariate tests: Correlation analysis}

Prior to estimate our model, we must examinate if there is presence of a multicollinearity problem. Multicollinearity refers to a situation in which two or more independent variables in multiple regression model are highly correlated. It can be detected through analyzing the Spearman correlation matrix. If the Spearman correlation coefficient exceed 0, 7 (limit fixed by Kervin, 1992), we conclude the presence of multicollinearity problem. Table 8 present the correlation coefficient associated to independent variables used in our model.

Table 8. Spearman correlation coefficients of the independent variables

\begin{tabular}{|c|c|c|c|c|c|c|}
\hline & ICDI & LNTA & PROF & END & LNCOT & CLA \\
\hline \multirow[t]{2}{*}{ ICDI } & 1 & & & & & \\
\hline & $0.000 * * *$ & & & & & \\
\hline \multirow{2}{*}{ LNTA } & 0.388 & 1 & & & & \\
\hline & $0.000 * * *$ & $0.000 * * *$ & & & & \\
\hline \multirow[t]{2}{*}{ PROF } & -0.025 & -0.331 & 1 & & & \\
\hline & 0.773 & $0.000 * * *$ & $0.000 * * *$ & & & \\
\hline \multirow[t]{2}{*}{ END } & 0.149 & 0.595 & -0.5043 & 1 & & \\
\hline & $0.063 *$ & $0.000 * * *$ & $0.000 * * *$ & $0.000 * * *$ & & \\
\hline \multirow[t]{2}{*}{ LNCOT } & 0.338 & 0.578 & -0.2651 & 0.3049 & 1 & \\
\hline & $0.000 * * *$ & $0.000 * * *$ & $0.000 * * *$ & $0.000 * * *$ & $0.000 * * *$ & \\
\hline \multirow[t]{2}{*}{ CLA } & 0.526 & 0.494 & -0.0590 & 0.1462 & 0.2853 & 1 \\
\hline & $0.000 * * *$ & $0.000 * * *$ & 0.645 & 0.068 & $0.000 * * *$ & $0.000 * * *$ \\
\hline
\end{tabular}

ICDI = Intellectual Capital Disclosure Index. LNTA = Log (total assets). PROF $=$ Earnings before interest and taxes/ total assets. END $=$ total debts / total assets. LNCOT $=$ Log (duration of the listing of the firm in the stock exchange in years). CLA is a dummy variable that equals one for high-tech industry, and zero otherwise. Panel A is firms with Tobin's Q is higher than or equal to "1". Panel B is firms with Tobin'Q is lower than less than "1". Significance levels $(*=10 \%, * *=5 \%$, *** $=1 \%)$.

The matrix of correlation of Spearman doesn't show any correlation higher than " 0.6 " between the independent variables. The highest correlation (0.595) is noted between the following variables: LNTA and END. However, this value doesn't exceed the limit fixed by literature. Thus, we conclude the absence of a multicollinearity problem. 


\section{Macrothink}

International Journal of Accounting and Financial Reporting

ISSN 2162-3082 2013, Vol. 3, No. 1

\subsection{Panel data tests}

We have used STATA to make the different statistics tests and the regressions of this sub-section.

\subsubsection{Test of presence of individual effect}

Table 8. Test of Chow of the presence of individual effect

\begin{tabular}{|l|l|}
\hline Fisher test & $47.138^{* * *}$ \\
& $(0.000)$ \\
\hline & $* * *$ significant at $1 \%$ \\
\hline
\end{tabular}

The results of this test allow to reject the null hypothesis $\mathrm{H}_{0}$ and to accept the alternative hypothesis: the presence of significant individual effects.

\subsubsection{Test of Hausman}

Table 9. Test of Hausman

\begin{tabular}{|l|l|}
\hline Chi 2 test & $0.316^{* * *}$ \\
\cline { 2 - 2 } & $(0.000)$ \\
\hline & $* * *$ significant at $1 \%$ \\
\hline
\end{tabular}

We have, also, used the test of Hausman in order to specify the model whether by taking into consideration the individual fixed or random effect. The Hausman test is not significant for our model, thus, we apply the specification in random effects.

\subsubsection{Heteroscedasticity test}

Table 10.Test of Breusch-Pagan

\begin{tabular}{|l|l|}
\hline Chi 2 test & $5.32 * *$ \\
\cline { 2 - 2 } & $(0.014)$ \\
\hline & $* *$ significant at $5 \%$ \\
\hline
\end{tabular}

Breush-Pagan test have confirmed the existence of heteroscedasticity problem for our Model. Thus, we use the method of GLM (generalized least squares) that takes into consideration the presence of heteroscedasticity. 


\subsection{Interpretation of the results of the multivariate analysis}

The multivariate regression results are presented in the following table:

Table 11. Results of multivariate analysis

\begin{tabular}{|c|c|c|c|}
\hline Variables & Coefficient & T-statistic & Probability \\
\hline constant & 4.09 & 4.98 & $0.000^{* * *}$ \\
\hline ICDI & 0.29 & 3.25 & $0.001^{* * *}$ \\
\hline LNTA & 0.69 & 3.08 & $0.001^{* * *}$ \\
\hline PROF & 0.54 & 0.80 & 0.421 \\
\hline END & 0.065 & 0.20 & 0.838 \\
\hline LNCOT & 0.043 & 2.03 & $0.043^{* *}$ \\
\hline CLA & 0.38 & 1.70 & $0.089^{*}$ \\
\hline Adjusted R-squared \\
Wald Chi 2 \\
Significance
\end{tabular}

The global quality of the empirical model is measured with adjusted R-squared, its equal to $35 \%$. This coefficient shows that the intellectual capital disclosure index of Tunisian firms and some of there characteristics including size, profitability, leverage, age and business classification explain $35 \%$ the value creation measured by the Tobin's Q.

The results in Table 11 support the notion that the firm value creation is strongly influenced by the extent of intellectual capital disclosure. The Intellectual Capital Disclosure Index contributes to explain positively and significantly at $1 \%$ level $(p=0.0000)$ the Tobin's Q. It has a value that is equal to 0.29 ; this means that when the Intellectual Capital Disclosure Index increases by a one unit, the extent of value creation increases by $29 \%$. Thus, our hypothesis is confirmed. This significant result illustrates a positive relation between the extent of disclosure about intellectual capital and Tobin's Q and confirms the signal theory. This significant relationship means that financial market values the intellectual capital information, which explains already the large difference between the market and the book value in our sample. The financial market assimilates intellectual capital as future growth opportunities, and as indicators of the strategic situation or measuring the long-term value and state of a company. Therefore, disclosure in this area may have considerable importance in the taking of investment and financing related decisions. Given the importance of intellectual capital, managers, which have private information that is not reflected in the firm's financial statements, disclose information about intellectual voluntarily to signal their real value and growth opportunities to financial markets and to attract potential investors. Our 
result corroborates with the study of Chahine and Mathieu (2003), of Béjar (2006), Gleason and Klock (2006) and of Bellalah and al (2010) who found the existence of a positive and significant relation between information about intellectual capital and firm value. However, our finding is in contradiction with the results of Dammak and al (2009) and of Cazavian (2003) that reveal a positive but not significant relation between intellectual capital disclosure and firm value. There result can be explained by the choice of the measure used for the extent of intellectual capital disclosure. It's probable that the used criterion is not sufficient to quantify this variable.

As expected, firm size has positive and significant correlation with firm value. This is in line with the "bigger the better" belief which expresses that bigger firms seem to offer better visibility on their future growth opportunities (Bilson and al, 2003 and Broye and Schatt, 2003b).

Even though, there is no known theoretical connection between firm value and its age, the coefficient of the variable LNCOT is positive and significant at 5\%. This result suggests that value creation is positively affected by firm age. Findings of our study can be explained by the fact that when the firm is older, it seem to create more value in financial market. This result joins the results of Bilson and al (2003), of Broye and Schatt (2003b) and of Ritter (1991),

For the variable END (refers to leverage), its coefficient is positive but not significant. This result can be explained based on economic theory. The debt effect supports the capital structure irrelevance hypothesis of Modigliani and Miller (1963) which suggest that financing decision (wether debt and equity) does not matter for firm value.

Our result for the variable PROF shows a positive but non-significant correlation between corporate profitability and value creation. This result is not coherent with the results of Ramezani, Soenen and Jung (2002) that reveal that corporate profitability enhances value creation in financial market. Our finding can be explained by the existence of other determinants of firm value in the financial market and deemed most relevant by investors: in knowledge-based economy, value creation is more positively and significantly correlated with disclosure about intellectual capital than corporate profitability.

The positive and statistically significant coefficient of the variable CLA highlights the fact that firm value is affected by business classification. Value creation of high-tech industries were significantly higher than those of low-tech industries because R\&D expenses in the high-tech industry was higher than that in the low-tech industry; this demonstrates that R\&D expenses spent on high-tech industries generate high information effects on accounting for firm values, relative to those spent on low-tech industries. This result is coherent with the results of Williams (2001) and of Eberhart, Maxwell and Siddique (2004).

Through the results of multivariate analysis, we note that firm value is more positively and significantly correlated with the extent of disclosure about intellectual capital (coefficient significant at 1\%) than some of firm characteristics as size, age (coefficient significant at 5\%), leverage, profitability and business classification (coefficient significant at 10\%). therefore, 


\section{MInstitute Macrothink $_{\text {Int }}^{\text {Intion }}$}

International Journal of Accounting and Financial Reporting

our study confirmed the pivotal role of intellectual capital in the valuation of firms and the determination of their future earnings. Reporting on intellectual capital allows resolving uncertainty about the firm, thereby improving the stock price and an increase in value, which is likely to be a key motivator for listed firms to voluntarily adopt disclosure of intellectual capital.

\section{Conclusion and implication}

The major interest of this study is that it contributes to the analysis of the behaviours of the listed Tunisian firms in matter of intellectual capital disclosure in annual reports and the examination of its effects on firm value creation. The results of our study highlight the role a company's intellectual capital play in value-creation. Based on weighted Intellectual Capital Disclosure Index, we have proved the relevance of intellectual capital information for valuating firm in financial markets.

This study has both theoretical and practical implications. From a theoretical standpoint, we developed a weighted Intellectual Capital Disclosure Index based on investors' needs and expectations and we revealed a positive relationship between the extent of disclosure about intellectual capital and firm value. From a practical standpoint, the study offers insights to policy makers and regulators in order to establish accounting policy and set standards. Our work shows that much of the informational needs about intangible do not appear in traditional financial statements. Modified reporting standards that specify additional types of information might better meet investor needs and mitigate problems of information asymmetry in capital markets.

However, our study has certain limits. The most important are its small sample of 50 companies listed on Tunisian Market Exchange and the manual analysis of the content of the annual reports. The measurement of the extent of disclosure about intellectual capital is based on weighted index that may involve subjective judgment on the part of the respondents. The lack of independent weighting has the potential to impact on the reliability of the results despite care taken in the analysis. Therefore, the findings of such research may not be generalized to different countries at different stages of development and with different business environments.

Nevertheless, there are a number of directions future research could take. The issues discussed in this study apply not only to the content analysis of corporate annual reports, but also to other formal documents issued by an organization, information intermediaries or stakeholders, as well as to informal dialogues between company representatives and interested parties. A comparative study for different countries with emerging capital markets might also be fruitful. Therefore, it would be interesting to duplicate this study in other countries, which have many similarities to the Tunisian environment. Last, an empirical study will follow this research to reveal the determinant of disclosure about intellectual capital. 


\section{Macrothink}

International Journal of Accounting and Financial Reporting ISSN 2162-3082 2013, Vol. 3, No. 1

\section{References}

Abdolmohammadi, M. J. (2005), Intellectual capital disclosure and market value, Journal of Intellectual Capital, Vol. 6, No. 3, pp. 397-416.

Amir, E., B. Lev. 1996, Value-relevance of nonfinancial information: The wireless communications industry. Journal of Accounting and Economics, 22: 3-30.

Arcelus F.J., Mitra D. and Srinivasan G. (2005), On the incidence of deferred taxes, intangibles and non-linearities in the relationship between Tobin's Q and ROI, Journal of Economics and Business, Vol. 57, pp. 165-185.

Arvidsson. S, (2003), Demand and Supply of Information on Intangibles - The Case of Knowledge-intensive Companies, dissertation, University of Lund: The Institute of Economic Research.

Barth. M. E and G. Clinch, (1998), Revalued financial, tangible, and intangible assets: associations with share prices and non market-based value estimates, Journal of Accounting Research, Vol. 36, pp.199-233.

Barth. M. E, M. B. Clement, G. Foster, and R. Kasznik, (2000), Brand values and capital market valuation, Review of Accounting Studies, Vol. 3, pp.41-68.

Beattie. V and S.Thomson, (2007), Lifting the lid on the use of content analysis to investigate intellectual capital disclosures, Accounting Forum, Vol. 31, pp.129-163.

Béjar. Y, (2006), La valeur informationnelle du capital immatériel : application aux entreprises technologiques nouvellement introduites en bourse (1997-2004), Thèse de doctorat, université Paris Dauphine.

Bellalah. M, Bouri. A and Chabchoub. A, (2010), L'évaluation des investissements immatériels, une étude empirique : Cas des entreprises tunisiennes, Colloque : la comptabilité, le contrôle et l'audit entre changement et stabilité.

Bilson C., R. Heaney, J. G. Powell, and J. Shi, (2003), The decision to voluntary Provide an IPO Prospectus Earnings Forecast : Theoretical Implications and Empirical Evidence, Document de travail Australian National University.

Bornemann M., Knapp A., Schneider U., and Sixl K. [1999], Holistic measurement of intellectual capital, International Symposium on Measuring and Reporting Intellectual Capital: Experience.

Bouden I. (2006), Identification des incorporels lors des regroupements d'entreprises : impact sur le marché financier français, Euro-mediterranean economics and finance review, Vol. 1, $\mathrm{n}^{\circ} 3$.

Brennan, Niamh; Connell, Brenda, (2000), Intellectual capital: current issues and policy implications, Journal of Intellectual Capital, Vol 1 (3), pp 206-240.

Breton. G and R. Taffler, (2001), Accounting Information and Analyst Stock 


\section{MInstitute Macrothink $^{\text {Int }}$}

International Journal of Accounting and Financial Reporting ISSN 2162-3082

Recommendation Decisions: A Content Analysis Approach, Accounting and Business Research, Vol. 31, N² 2, Spring, pp. 91-101.

Broye G., and A. Schatt, (2003), Sous évaluation à 1 'introduction et cession d'actions par les actionnaires d'origine : Le Cas français, Finance Contrôle Stratégie, Vol 6, № 2, pp. 67-89.

Bughin, J., Chui, M., and Johnson, B. (2008). The next step in open innovation. The McKinsey Quarterly, June 2008.

Buzby. S, (1975), Company size, listed versus unlisted stocks, and the extent of financial disclosure, Journal of Accounting Research, spring pp.16-37.

Casta J. F., Ramond R. and Escaffe L. (2007), Investissement en capital immatériel et utilité de l'information comptable : Étude comparative des marchés financiers européens, Working paper.

Cazavan. A, (2004), Le ratio market-to-book et la reconnaissance des immatériels - Une étude du marché français, Comptabilité Contrôle Audit, Tome 10, Vol. 2, décembre.

Chahine. S and J-P Mathieu, (2003), Valorisation stratégique par contextes de valeur : le cas des introductions sur le Nouveau marché, Revue Finance Contrôle Stratégie, Vol. 6, n 2, pp. 91-114.

Chauvin, K.W and M. Hirschey, (1994), Advertising, R\&D Expenditures and the Market Value of Firms, Financial Management, Vol.22, n4, pp 128-40.

Chen.M, S. Cheng and Y.Hwang, (2005), An empirical investigation of the relationship between intellectual capital and firms' market value and performance, Journal of intellectual capital, pp159-176.

Chung, K and Pruitt, S.W., 1995. A simple approximation of Tobin's Q. Financial Management, Vol 23 (3), pp70- 74.

Cooke, T.E. (1989), Voluntary corporate disclosure by Swedish companies, Journal of International Financial Management and Accounting, Vol. 1 No. 2, pp. 171-195.

Clarkson P. M., A. Donth, G. D. Richardson, et S. E. Sefcik, (1992), The Voluntary inclusion of earnings forcasts in ipo prospectuses, Contemporary Accounting Research, Vol. 2, pp. 601-626.

Dammak. S, M. Triki and Y. Boujelbene, 2009, Offre volontaire d'informations sur le capital intellectuel et marché financier, Acte publié dans La place de la dimension européenne dans la Comptabilité Contrôle Audit, Strasbourg : France.

Decarolis D. M and D. L. Deeds, (1999), The impact of stocks and flows of organizational knowledge on firm performance: An empirical investigation of the biotechnology industry, Strategic Management Journal, Vol. 20, pp. 953-968.

Deeds D. L, D. M. Decarolis, and J. E. Coombs, (1997), The impact of firm-specific capabilities on the amount of capital rose in an initial public offering: Evidence from the 
biotechnology industry, Journal of Business Venturing, Vol. 12, pp. 31-46.

Delgado-Gomez J. M., Ramirez-Aleson M. and Espitia-Escuer M. A. (2004), Intangible resources as a key factor in the internationalization of Spanish firms, Journal of Economic Behavior \& Organization, Vol. 53, pp. 477-494.

Dempsey, S., Gatti, J.F., Grinnell, D.J., and Cats-Baril, W.L. (1997). The use of strategic performance variables as leading indicators in financial analysts' forecasts. Journal of Financial Statement Analysis, 2(4), 61-79.

Eberhart, A. W. Maxwell, and A. Siddique, 2004, An Examination of Long-Term Abnormal Stock Returns and Operating Performance Following R\&D Increase, Journal of Finance 59, 623-650.

Eccles. R. G, and S. Mavrinac, (1995), Improving the corporate disclosure process, Sloan Management Review, summer, pp. 11-25.

Eccles. R. G, R. H. Hertz, E. M. Keegan, and D. M. Phillips, (2001), The Value Reporting Revolution: Moving Beyond the Earnings Game, New York, United States of America: John Wiley and Sons.

Feranadez. E, J. M. Montes and C. J. Vazquez, (2000), Typology and Strategic analysis of intangible resources: A resource-based approach, Technovation, Vol. 20, pp. 81-92.

Firer C. and G. Meth (1986), Information disclosure in annual reports in South Africa, Omega International Journal of Management Science, vol. 14, n5, pp.373 - 382.

Frotiee, P and Andrieu, M, (1998), valeur actionnariale et immatérielle, Analyse financière, $\mathrm{n}^{\circ} 116$.

Gantenbein, P and Volonté, C, (2012), Director Characteristics and Firm Performance, Working Paper, University of Basel, Faculty of Business and Economics.

García-Meca, E, (2005), « Bridging the gap between disclosure and use of intellectual capital information », Journal of Intellectual Capital, Vol. 6, n .3, p. 427.

García-Meca. E and I. Martínez, (2007), The use of intellectual capital information in investment decisions: An empirical study using analyst reports, The International Journal of Accounting, Vol 42, pp. 57-81.

Gleason K and Klock M. (2006), Intangible capital in the pharmaceutical and chemical industry, The quarterly review of economics and finance, Vol. 46, pp. 300-314.

Hanifa, R. M. and Cooke T.E (2002), Culture, Corporate Governance and Disclosure in Malaysian Corporations. ABACUS, Vol. 38, 317-349.

Henning L.H., Lewis B.L. and Shaw W.H. (2000), Valuation of the components of purchased goodwill, Journal of accounting research, Vol. 38, $\mathrm{n}^{\circ} 2$, pp. 375-386.

Hsiung, $\mathrm{H}$ and Wang, J, (2012), Value creation potential of intellectual capital in the digital content industry, Investment Management and Financial Innovations, Volume 9, Issue 
2.

Ittner. C.D, D.F Larcker and T. Randall, (2003), Performance Implications of Strategic Performance Measurement in Financial Services Firms, Accounting, Organizations and Society, Vol. 28, pp. 715-74.

Jog V., and B. J. Mconomy, (2003), Voluntary disclosure of management earnings forecasts in IPO prospectuses, Journal of Business, Finance and Accounting, Vol. 30 (1/2), pp. 125-167.

Kaplan. R. S and D. P. Norton, (2001b), Transforming the balanced scorecard from performance measurement to strategic management, Accounting Horizons (March), pp.87-104.

Kennerley. M, A. Neely and C. Adams, (2003), Survival of the fittest: measuring performance in a changing business environment, Measuring Business Excellence, Vol. 7, n .4, pp.37-43.

Kervin. J, (1992), Methods for business research, New York: Harper.

Labegorre. F., and S. Boubaker, (2005), Publication volontaire de prévisions et rentabilités initiales : le cas des admissions à la cote du second marché français (1994-2000), Banque et Marché, $\mathrm{N}^{\circ} 77$, pp. 35-46.

Lang. M and R. Lundholm, (1993), Cross - Sectional Determinants of Analyst Rating of Corporate Disclosure, Journal of accounting Research, Vol 3, n², pp. 246 -271.

Léger J-Y., (2003), La communication financière, Dunod.

Lev. B, (1992), Information disclosure strategy , California Management Review, summer.

Lev. B and T. Saugiannis, (1996), The capitalization, amortization and value relevance of R\&D, Journal of Accounting and Economics, Vol.21, pp.107-138.

Lev. B and E. Amir, (1996), Value Relevance of non-financial information: the wireless communications industry, Journal of Accounting and Economics, Vol. 22, pp. 3-30.

Lev. B and P. Zarowin, (1998), The market valuation of R\&D expenditures, working paper, New York Stern University.

Lev. B and P. Zarowin, (1999), The boundaries of financial reporting and how to extend them, Journal of Accounting Research, Vol.37, Autumn, pp.353-85.

Lev. B, (2001), Intangibles: management, measuring and reporting, Brookings Institution Press, Washington, $D C$.

Lev. B, (2002), Communicating Knowledge Capabilities, disponible à l'adresse http://pages.stern.nyu.edu/ blev/communicating.doc.

Lev. B and S. Radhakrishnan, (2003), The Measurement of firm-specific organisation capital, Working Paper, $\mathrm{n}^{\circ} .9581$.

Lev, B. and Daum J., (2004), The dominance of intangible assets: consequences for enterprise management and corporate reporting, Measuring Business Excellence, Vol. 8. 


\section{Macrothink}

International Journal of Accounting and Financial Reporting ISSN 2162-3082 2013, Vol. 3, No. 1

Liang. C and M. Yao, (2005), The value relevance of financial and nonfinancial information: Evidence from Taiwan's information electronics industry, Review of Quantitative Finance and Accounting, Vol. 24, pp. 135-157.

Lindenberg, E., and Ross, S., (1981), Tobin's q ratio and industrial organization, Journal of Business, Vol 54, pp1 - 32.

Louzzani. Y, (2004), Immatériel et performances des entreprises: Cas des entreprises industrielles en France sur la période 1994-1998, Thèse pour le Doctorat en Sciences de Gestion De l'Université Toulouse I.

Mavrinac. S, and A. Siesfeld, (1997), Measures that matter, an exploratory investigation of investors information needs and value properties, In Enterprise Value in the Knowledge Economy, OECD and Ernst \& Young Center for Business innovation, Cambridge, MA.

Michailesco C, (1999), Une étude empirique des déterminants de la qualité de l'information iffusée par les entreprises françaises au cours de la période 1991-1995, ComptabilitéContrôle-Audit, Tome 5, vol 1, pp 83-108

Miller. W, (1999), Building the Ultimate Resource, Management Review, Jan. 1999, 42-45.

Modigliani, F. and Miller, M. H. (1963). Corporate Income Taxes and the Cost of Capital: A Correction. American Economic Review, 53, 433-43.

Montgomery, C., and Wernerfelt, B., (1988). Tobin's q and the importance of focus in firm performance. American Economic Review, Vol 78 (1), pp 246- 250.

Naser K and Nuseibeh R, (2003), Quality of financial reporting: evidence from the listed Saudi nonfinancial companies, The international journal of accounting, vol 38, pp 41-69.

Pratt, John (2002a), Critical Criminology and the Punitive Society: Some New Visions of Social Control, in Kerry Carrington and Russell Hogg (eds.) Critical Criminology: Issues, Debates, Challenges, pp. 168-184. Cullompton: Willan Publishing.

Pratt, John (2002b), Punishment and Civilization. London: Sage.

Previts. J, R. Bricker, T. Robinson and S. YOUNG, (1994), A content analysis of sell side financial analysts company reports, Accounting Horizons, Vol. 8, $\mathrm{n}^{\circ} 2$, pp. 55-70.

Rajan, R. G. and Zingales L. (1995), What Do We Know about Capital Structure? Some Evidence from International Data, Journal of Finance, 50, 1421-1460.

Ramezani C. A, Soenen L.and Jung A (2002), Growth, corporate profitability, and value creation, Financial Analysts Journal, Vol 62 (6), pp.56-67.

Ritter, J.R., 1991, The Long-Run Performance of Initial Public Offerings, Journal of Finance, 46, 3-27.

Robbins, W. A., and Austin, D. R. (1986). Disclosure quality in governmental financial reports: an assessment of the appropriateness of a compound measure, Journal of Accounting Research, Vol 24(2), pp 412-421. 


\section{Macrothink}

International Journal of Accounting and Financial Reporting

ISSN 2162-3082

Rogers. R and J. Grant, (1997), Content analysis of information cited in reports of sell-side financial analysts, Journal of Financial Statement Analysis, Fall, Vol 3, n 1, pp. 17-30.

Schipper, K. (1991). Analysts' forecasts. Accounting Horizons, 5, 105-131.

Shevlin. T, (1996), Value Relevance of non financial information: the wireless communications industry: a discussion, Journal of Accounting and Economics, Vol. 22, pp. $31-42$.

Singleton, W. R. and Globerman, S. (2002), The Changing Nature of Financial Disclosure in Japan” International Journal of Accounting. Vol. 37, pp.1-17.

Stewart. G. B, (1991), The Quest for Value, New York, Harper Business.

Thibierge, C. (2001), Actifs immatériels, valorisation boursière et contraintes d'endettement ; étude empirique sur les marchés français et espagnol, Working paper, series, 2001, ESCP-EAP Département de finance.

Williams. S.M, (2001), Is intellectual capital performance and reporting practices related?, Journal of Intellectual Capital, Vol. 2, N³, pp. 192-203. 